V. I. Panchenko, Doctor of Philosophical Science, Professor

Taras Shevchenko National University of Kyiv

60, Volodymyrska Street, Kyiv, 01033, Ukraine

\title{
CULTURAL EXPERTISE OF CULTURE RESOURCES
}

The article studies cultural expertise, importance of which grows within conditions of social and cultural transformations in modern society. It is underlines the features of cultural expertise for the analysis and solution of social problems. Cultural expertise is the basis for different projects: cultural, urban, artistic. Cultural studies mean cumulative knowledge for the expert knowledge.

Expert assessments of processes and objects, which cannot be calculated, are based on their own judgments. Cultural expertise includes analysis of social reality: values, public opinion, interests, traditions and rules. All this must be expressed in quantitative terms. The question of the appropriateness for using axiological parameters is still open.

It is stressed that the cultural expertise is important on different stages of the project making activity: planning, support, implementation, evaluation of its ef fectiveness. At the national level decision-making procedure should include the recommendations of academic experts for the objective information and understanding the results that will be achieved in the future. The procedure of cultural expertise legitimizes state decisions for the society.

Cultural resources of cities and regions are assets for creative economy implementation. Cultural expertise of culture resources is a main component in the process of this realization on the national level. Cultural, educational and regional policies in Ukraine should consider cultural studies knowledge as basic for cultural expertise, which can be seen as an instrument in the context of social reality. An important task of the cultural expertise is the correlation between existing and desired image of the city with its cultural potential. The image is constructed purposefully; it represents the desired vision of the city and social relation to it The successfully created image is capable to transform the idea and the mission of the city from the "model" to the program of activities.

Keywords: cultural project, cultural expertise, cultural policy, expert evaluation, creative economy, cultural resources, urban policy.

УДК 130.2:008

А. А. Семененко, канд. філос. наук, ст. викладач Національна академія образотворчого мистецтва і архітектури вул. Вознесенський узвіз, 20, м. Київ, 04053, Україна semlika71@gmail.com

\section{НОВІТНІ КУЛЬТУРНІ ПРАКТИКИ У ФОРМОТВОРЧИХ ІНДУСТРІЯХ СУЧАСНОСТІ}

У статmі здійснений аналіз актуальних формотворчих тенденцій з точки зору їх зв'язку з новітніми культурними практиками, визначеними економічним, технічним та соціальним контекстом культури. Використовуючи оптику культурної антропології та визначені сучасними мислителями домінанти цивілізаційного руху, досліджено вектори проективної активності людства. Показана еволюція мови та цілей предметних практик, означені та охарактеризовані нові архітектурно-дизайнерські стилі (рециклінг-, поп-, еко-, рекреаційний, моушн-, медіа-, мультимедійний, мультисенсорний дизайн тощо). Розмаїття дизайнерських стилів сьогодні багато в чому пояснюється прагненням поєднати розмежовані ходом суспільного прогресу інтенції формотворення - відповідність вимогам й характеру сучасності та збереження онтологічних засад, що забезпечують людині відчуття "дому" та власної індивідуальності. Гармонізувати їх вдається дизайнерським практикам, що реалізують у проективності комунікативний, інтерактивний потенціал, залишаючи простори побутування людини живими і людяними.

Ключові слова: культура, культурні практики, просьюмеризм, партисипація, мультимедійний та мультисенсорний дизайн, е-культура, гібридне мистецтво.

Постановка проблеми. Одна з актуальних задач сучасного гуманітарного знання - це осмислення новітніх та традиційних культурних практик, зумовлених бурхливими соціотехнічними перетвореннями. Дослідження характеру та напрямків проективної активності, втіленої у предметності (реальній та віртуальній), дає змогу глибше зрозуміти характер цивілізаційних трансформацій, їх зв'язок із сутнісними вимірами людського.

Аналіз досліджень і публікацій. Теоретичну базу дослідження складають праці, присвячені загальним характеристикам сучасної культури, 3. Баумана, Ж. Бодріяра, Гі Дебора, М. Маклюена, Х. Ортега-і-Гассета, Р. Сеннета, Е. Тоффрлера, Е. Фромма, Т. Хофштеде та ін. Важливим внеском в розуміння характеру актуальних формотворчих індустрій стали дослідження різних аспектів сучасності: ролі інформації - Д. Белл, Дж. Гелбрейт, 3. Бжезинський; комунікативної проблематики - Е. Басін, В. Березін, 3. Гершкович, Н. Луман та ін.; віртуальності - Ф. Джеймісон, Ж.-Ф. Ліотар, П. Вірільйо, Ж. Дельоз, С. Жижек, М. Хейм, Н. Карпицький, Н. Маньковська, Н. Носов, А. Севальников, С. Хоружий; медійності - В. Беньямін, М. Кастельс, Н. Луман, В. Савчук, В. Возчиков, Н. Кириллова. Розгляд архітектурно-дизайнерської діяльності у вимірі соціокультурного буття - Р. Арнхейм, В. Аронов, В. Ганзен, В. Генісаретський, Г. Лола та ін. - закладає основи аналізу її у парадигмі сутнісних вимірів людського світу. Висвітлені у роботах російських фрілософрів В. Бичкова та Н. Маньковської проблеми некласичної естетики забезпечують осмислення новітніх формотворчих тенденцій новим понятійним дискурсом. Однак поліморфічність культурних форм очікує на подальші теоретичні розвідки, чому й присвячена представлена стаття.

Мета статті. Проаналізувати сучасні культурні практики як чинник новацій формотворчих індустрій, що виявляє механізм переводу культурних кодів у предметні форми.
Виклад основного матеріалу дослідження. Антропологічні розмисли сучасності знаходяться у напруженому пошуку врівноваженості різних теорій людинознавства, йдучи шляхом активного вивчення конкретики людського світу. Формовияви культури, звичайно, не збігаються з людським життям, але здатні розкрити його смисли та проблемні вузли, адже завжди задаються сутнісною константою - мірою людського. В цьому сенсі перспективною для антропологічних пошуків виявляється площина гуманітарного знання, яка, досліджуючи природу людини, розкриває засади світоглядних зрушень, цього горизонту всіх культурних розбудов.

Теоретичні розвідки XX ст. означили суттєві трансформації соціокультурного простору і запропонували нові назви доби, що відповідають характеру економічних та соціальних відносин сучасності. Так, сформулювались терміни "суспільство споживання" (Ж. Бодрійяр, Е. Фромм), "постіндустріальне суспільство" (Е. Тоффрлер), "суспільство спектаклю" (Гі Дебор), "індивідуалізоване суспільство" (3. Бауман), "повстання мас" (Х. Ортега-і-Гассет), "падіння публічної людини" (Р. Сеннет) тощо. Паралельно досліджувались феномени ринку, реклами, піару, просування товарів та послуг. На певному етапі сформувалась негативна оцінка культури споживання та консьюмеризма (Г. Маркузе, Ж. Бодріяр). Але паралельно формувався і більш лояльний погляд на неї, що втілилось у концепції просьюмеризму i, відповідно, людинипросьюмера. Е. Тофффлер у "Третій хвилі" наполягав на тому, що, незважаючи на негативні характеристики суспільства масового споживання, у другій половині XX ст. виникають передумови нових моделей поведінки, коли людина має можливість самостійно налаштовувати своє існування у просторі створених для нього об'єктів [10]. 
Просьюмер - людина, яка конструює реальність під себе з предметності, що ії оточує, тим самим створюючи щось якісно нове. Ця тенденція do it yourself - DIY (зроби сам), спираючись на архаїчні практики "ручної" праці, що були витіснені на периферію культурних практик машинним виробництвом індустріальної доби, у постіндустріальну добу реінкарнується не тільки у повсякденності, а й активно розвивається у сфері художньої культури. Так, у другій пол. XX ст. виникають субкультурні практики виробництва продуктів, незалежних від мейнстрима, зааганжованого ідеологією, модою, суспільними стереотипами, комерційним диктатом: фензіни, самвидав, андеграундна музика, заснована на "етиці DIY" (прихильники DIY називають себе true (справжні, істинні)) тощо.

Ця людська активність - потреба справжнього опікування власним буттям, - що має онтологічний статус у структурі людського й підкріплена прагненням особистісного зростання та підвищення компетенції, бажанням підкреслити свою індивідуальність, стає основою нової економічної практики, яку Ф. Бродель у своїй праці "Матеріальна цивілізація, економіка та капіталізм XV-XVIII" означив як "позаринкова економіка" [5]. Популярність майстер-класів handmade з кулінарії, художньої творчості, бісероплетіння, скрапбукінгу, печворку, квілінгу, фрлористики, декорування тощо свідчить про DIYорієнтованість суспільства, і цей запит миттєво опановується ринком. Яскравим прикладом цього $є$ розвиток DIY\&Household-галузі, представленої будівельними та меблевими магазинами формату DIY, такими як IKEA, Leroy Merlin, Castorama, OBI тощо. Покупцю пропонується широкий вибір "конструкторів" для будівництва, оздоблення, меблювання життєвих просторів [7, с. 165]. Такі практики $є$ створенням нового предмета з доступних елементів природного або соціокультурного середовища та повертають у предметний простір культури індивідуальність, природність, унікальність.

Архітектурно-дизайнерська діяльність сучасності реагує на нові культурні запити людини виробленням стратегій, що розширюють горизонти вибору. Так постає тактична урбаністика, де впровадження змін у міському середовищі проходить етап втілення тимчасового архітектурнодизайнерського проекту, який привертає увагу спільноти до об'єкта змін, стимулює обговорення, проведення воркшопів 3 жителями й врешті слугує прототипом кінцевого проекту; відбувається проектування просторів вільного планування, де людина сама визначає розміри та функції життєвих приміщень, розвиток DIY-руху, провісниками якого $€$ суспільні майстерні, де за гроші надаються матеріали, інструменти, приміщення, послуги професіоналів для втілення задуманого людиною проекту (столярні, ткацькі, гончарні, ювелірні вироби тощо).

Подальше теоретичне осмислення DIY-культури втілюється у концепцію Акселя Бранса, австралійського дослідника, який пропонує термін produsage (цей неологізм утворений злиттям слів to produce - "виробляти" та usage - "користь, використання" й відображає опанування людиною нового середовища виробництва, споживання та комунікації - цифрового), який описує ситуацію споживацького досвіду, що, користуючись відкритим софтом, програмним забезпеченням 3 відкритим кодом, створює певні продукти для загалу. Він називає ïx Creative Commons - тексти (wiki-знання), культурні артефакти (музика, відео, літературні твори, колажі тощо), які колективно створюються, редагуються та модеруються [13]. Така реальність $€$ втіленням концепції Генрі Джеккінса про культуру партисипації, або культуру співучасті, в якій він стверджує, що всі користувачі Мережі $є$ одночасно її творцями й учасниками виробництва тих додаткових реальностей, які вона продукує [14].
Наприклад, нових масштабів та можливостей набуває така культурна практика, як доброчинність (спонсорство, донорство, краудфандинг, волонтерство), перетворюючись на практику громадської співучасті і відповідальності, де он-лайн-активність реалізується в офр-лайн-події суспільного та особистого життя. Цікаво, що краудфандингова підтримка спрямовується як на соціально незахищені суб'єкти та об'єкти культури, так і на стартапи, наукові дослідження, кіновиробництво, образотворчу діяльність, музеї тощо. Таким чином мають шанс реалізуватись багато "неформатних" ідей, що не мали такої можливості в умовах ринкової та ідеологічної кон'юнктури.

Культура партисипації здатна також трансформувати класичні, традиційні культурні сфери, яким для виживання необхідне осучаснення їхньої комунікативної мови. Наприклад, у концепції "музею 2.0", партисипативного музею, функціонування сучасних інституцій, де зберігаються і транслюються культурні цінності та об'єкти, передбачає не тільки відвідування і споглядання, а й можливість створити щось нове. Тут активно використовуються цифровий інструмент, цифрові прилади, що доповнюють колекції, виставки та потребують машинолюдської взаємодії й інтенсифікують людський досвід. Або з'явилось та розвивається партисипативне мистецтво, в якому акцент переноситься зі створення об'єкта до створення процесу й засноване на залученні спільноти, взаємодії художника з аудиторією. Партисипативне мистецтво може втілюватись у мікроурбаністичних тактиках як засіб репрезентацій мистецьких та архітектурнодизайнерських продуктів, як соціальний дизайн або як мистецька провокація. Нові культурні практики формують запити, що створюють нові культурні групи (ефективні партнерства) і професії (анімація культури).

Сучасний етап інформаційної революції, започаткований зрушеннями в інформаційних технологіях, появою телебачення, глобальної комп'ютерної мережі Інтернет та поширенням віртуального простору, виводить людську культуру на якісно новий рівень комунікації, де швидкість та доступність інформації, а також надзвичайні можливості спілкування складають основу стрімкого генезису нових культурних форм. Самі назви доби: "цифрове суспільство", "медіа-поліс", "інтернет-галактика", "кібер-суспільство", "кібер-культура", "кібер-простір", "електронний мегаполіс", "цифрове суспільство", "інфосфрера", "мережеве суспільство" тощо - свідчать про потужну хвилю культурного розвою, хвилю злиття людини з технікою, в якій остання виступає інструментом не тільки біологічної, а й соціальної еволюції.

Мережа віртуальної комунікації трансфрормує соціальну дійсність настільки глибоко, що теоретиками висуваються гіпотези кінця політики (Т. Хофштеде) та кінця геограсрії (М. Маклюен), які є провісниками розбудови всесвіту кібер-простору з його необмеженими можливостями. Так, технологічна основа сучасної цивілізації, її інформаційно-комунікаційні технології визначають єдність культурних форм інформаційного суспільства, що теоретики класифрікують як глобалізацію та уніфрікацію культури. Але те саме відкриває й не бачені раніш можливості єднання i спілкування людей не на основі територіальної близькості або мовної єдності, а на засадах духовної, релігійної, моральної, етнічної або будь-якої іншої спорідненості.

Новий рівень розвитку технологій породжує нову культуру - електронну, віртуальний простір і час, електронний статус самої людини, формуючи, по суті, "третю природу" - світ віртуальних феноменів. Відбуваються епохальні зміни у сферах економіки, освіти, комунікації, творчості - вони змінюють форму свого буття з реальної на цифрову, симуляційну за допомогою інформаційних технологій, що створюють єдиний інформаційний простір, віртуальні способи вираження, ліберальність контенту та використовують дистанційні технології. 
Дослідники антропологічних вимірів сучасної культури констатують: "Сучасна людина - це вже не просто Homo Sapiens, в значній мірі віртуалізований біосоціоелектронний суб'єкт, що володіє активністю як у сфері своєї тілесної природи, соціальної практики, так і у новій якості електронно-віртуального суб'єкта, який має технологічні надможливості (подолання просторово-часових границь та швидкостей) й включений у світову інтернетспільноту" [1]. Е-культура має два типи втілення. Перший - це електронна форма традиційних культурних об'єктів (електронні музеї, бібліотеки, виставки тощо). Другий поява та розповсюдження об'єктів, електронних за формою і за змістом (комп'ютерні ігри, програми, соціальні мережі, Інтернет, цифрові твори мистецтва тощо) [2].

Сучасне формотворення - це тісна співпраця вчених, інженерів, виробників, спеціалістів масмедіа та митців з вибудовування нових предметних та віртуальних форм, що відповідають змінюваному досвіду сучасної людини. Арт-об'єкти архітектурно-дизайнерської та мистецької творчості сьогодні $€$ продовженням наукових досліджень й експериментів (біології, фрізики, інформатики, кібернетики, досліджень штучного інтелекту, візуалізації інформації), втілюючи їх в аудіовізуальне технологічно й/або електронно сформоване середовище, доступне арт-реципієнтам не тільки у формі споглядання, а й для контактної взаємодії. Таке гібридне мистецтво виходить за межі жанровості, розмиваючи границі між живописом, скульптурою, інсталяцією, кіно, перформансом, й об'єднує науку, соціально-політичний контекст, поп-культурні пріоритети та синтезує всі можливі форми психоемоційного впливу на людину, створюючи навколо неї психомоторну систему масової комунікації з метою емоційно-тонізуючого або компенсаторно-рекреаційного впливу. Тут з'являються нові напрямки: медійна архітектура, геопросторова розповідь, використання робототехніки та штучного життя.

Російські дослідники В. Бичков та Н. Маньковська, здійснюючи філософсько-естетичний аналіз арт-практик у добу техногенної цивілізації, визначають три сфери, у які трансформуются традиційні мистецтва: організація всеохоплюючого середовища перебування людини, шоубізнес та новітнє дигітальне мистецтво на основі мультимедіа у просторах віртуальної реальності. Так фрормується ряд нових експериментальних мистецтв, втілених у артоб'єктах, артефактах, інсталяціях, акціях, енвайронментах, хепенінгах, перформансах, арт-проектах та арт-практиках, що розвинулись на мультимедійній основі - у кіно, телебаченні, сучасних шоу, у відеоарті, комп'ютерній графріці, комп'ютерних інсталяціях, сетературі, трансмузиці, інтернет-арті, інтерактивному мистецтві, віртуал-арті та інших новітніх видах арт-практик: медіа-арті (трансмишен-арт, експериментальне кіно) та технологічних мистецтвах (електронік-арт, робото-арт, геномік-арт) [6].

Проектування сьогодні також $є$ виробленням "нової мови", заснованої на багатстві антропологічних стосунків зі світом, й оперує новими пластичними, "неречовими" параметрами, активно залучаючи науково-технічні досягнення та перебираючи на себе функції медицини, шоу-індустрії та мистецтва. У суспільні та індивідуальні простори вводяться кінозасоби, психотерапевтичні та психопрофілактичні пристрої, лазерні установки, освітлювальне обладнання й інша театральна техніка, голографія, стереоскопічні прилади, здатні відтворювати рухомі зображення. Інтерактивність стає константою формотворення й складає основу нових галузей дизайн-активності: моушн-, медіа-, мультимедійного та мультисенсорного дизайну тощо, які, спираючись на науково-технічні досягнення, реалізують ідеї комунікативності, експозиційності та естетичності життєвого простору. Так, інтерактивність комп'ютерних засобів дозволяє підключати людину (відвідувача-користувача) до процесу проектування візуальних образів на поверхні мультимедійних об'єктів чи впливати на його форму.

Теоретичні розвідки новітніх тенденцій проектування визначають, що таким мультимедійним дизайн-об'єктам властиві: полісенсорність як результат інтегрованого впливу мультимедійного середовища; інтерактивна трансформованість; пластичність; змінність сенсорних параметрів (форми, кольору, звуку тощо), які спричиняють імпровізаційну неоднозначність і множинність інтерпретацій образу; процесуальність (можливість переміщення у віртуальному просторі та часі); нелінійність часу; взаємопов'язаність віртуальних подій і підпорядкованість всіх компонентів твору як волі автора (на етапі створення), так і відвідувача-користувача (в ході процесу активної взаємодії з об'єктом) [12].

Рівні та фооми інтерактивної взаємодії мають градацію: лінійна, реактивна, тактильна [10]. Так, лінійна взаємодія присутня в мультимедійних об'єктах, коли зміна аудіовізуальних зображень на їх поверхні не пов'язана з попередніми повідомленнями й втілює визначений автором сценарій. Прикладом такої взаємодії $\epsilon$ дизайн предметно-просторового середовища музею BMW в Мюнхені, де стіни зі світлодіодними мультимедійними панелями відображають динамічні графічні зображення. Інтерактивні відеопроекції на декілька поверхонь формують інтер'єрні та екстер'єрні відеомапінги або мистецькі інсталяції, що є складовою святкових шоу та рекламних акцій. Це є, наприклад, складовими проектів австралійського художника Девіда Аткінса, визнаного авторитета та провідного фахівця сучасної індустрії розваг, засновника австралійської компанії DAE (David Atkins Enterprise), що здійснює креативне наповнення та продюсування багатьох масштабних подій (серед них три найбільш технологічні події минулих років: "Альфа-Шоу 4D", відкриття чемпіонату світу з регбі в Окленді (Нова Зеландія) та церемонія відкриття XII Арабських ігор у Досі).

Реактивна (від reaction - "дія у відповідь") взаємодія активує різні стратегії подачі інформації на поверхні об'єкта. Саме такий рівень інтерактивності присутній у сенсорних панелях, різноманітних інформаційних стендах (IP Board, IPBoard LED Touch Screen, інтерактивні дошки SMART Board), що можуть бути створені за допомогою резісторних, поверхнево-акустичних, інфрачервоних екранів або сенсорного "розумного" скла (smart glass), та в інтерактивних відеопроекціях на площини (огороджувальні поверхні та обладнання). В цих об'єктах дії кожної людини (відвідувача-споживача) активують відповідну команду, яка закладена в програмно-апаратний комплекс мультимедійного об'єкта. Це можуть бути також інтерактивні сенсорні підлоги (цифрова підлога або відеопідлога) - світлодіодне покриття, яке дозволяє відображати на поверхні різні візуальні ефректи в залежності від присутності на ній об'єктів та їхніх пересувань. Така тенденція втілена в інтер'єрах музею Dornier Aerospace Museum (Фрідріхсгафен, Німеччина), Porsche Museum (Штутгарт, Німеччина) від компанії Jangled Nerves, інтер'єрі CERN - Universe of Particles від архітектурного бюро Atelier Brückner (Женева, Швейцарія), "Єврейського музею і центру толерантності" (Москва, РФ); виставкового центру Level Green від J. Mayer H. (Вольфсбург, Німеччина), магазину Louis Vuitton від архітектора Петера Маріно (Гонконг, КНР), експозиційного центру VW Dataterrain Exhibition Space (Boльфсбург, Німеччина), Water Planet Design від компанії Urban A\&O (Сан-Франциско, Каліфорнія, США).

Третій рівень інтерактивності присутній у кінетичних композиціях з їх множинною взаємодією, пов'язаною 3 безліччю попередніх повідомлень, втілених у абстрактні 
форми та образи. Такі автономні, динамічні й інтерактивні конструкції взаємодіють одна з одною та з будь-яким відвідувачем за допомогою трансформацій фрорми, візуальних ефректів і аудіосупроводу. Саме можливість втручання у структуру твору надає виняткового значення кінетичному мистецтву серед інших інтерактивних мистецьких практик. На цьому засновані проекти інженера і кібернетика Гордона Паска - його інсталяції з інтерактивними роботами ("Діалоги мобілів" (The Colloquy of Mobiles)) та розробки адаптивної архітектури (нереалізований проект Палацу розваг, що, не маючи визначеної функції, за задумом, міг трансформуватись в залежності від потреб у простори для освіти, спорту, театральних вистав, художніх виставок тощо). На цих ідеях розвивається нова кібернетична та кінетична архітектура.

У світлі цього стають зрозумілими як сучасні дизайнпрактики, так і обрії найближчого майбутнього. Перспективними напрямками проектної культури $€$ сьогодні саме мультисенсорний дизайн, який звертається безпосередньо до органів чуття людини: "...дизайн набуває все більшої інноваційності та художності, причому художнє начало у дизайні вже не може транслюватись лише візуальними каналами - воно повинно охопити тілесні, світлові, звукові, поведінкові аспекти людського буття. Лише за цих умов дизайнери бачать можливість забезпечення повноцінного інтерфейсу між людиною та іï предметним оточенням. ...Ця культура, протиставлена традиційній, часто розглядається як основа дизайну майбутнього. ІІї то потрактовують як всеосяжне поняття, яке включає в себе й "екранну культуру" і "розречевлене" середовище, де речі все більше заміщуються послугами, то виокремлюють як дещо самостійне" [11, с. 9].

Вважається, що синтез таких полімодальних засобів, здатних впливати на різні органи людських відчуттів, забезпечить формування різноманітного, активного, експресивного та адаптивного предметно-просторового середовища з новими якостями, адекватними складності та динамічності людського самопочуття. Так, практика проектування зосереджується на "другорядних" 3 точки зору технологічної культури функціях середовища: психотерапевтичній та психопрофілактичній.

Сучасні реалії інформаційного суспільства, яке відзначається надзвичайним поширенням та розповсюдженням віртуальності, знецінюють традиційні механізми діагностики автентичності буття. Експансія "екранної культури" перетворює життєві простори людини: експресія візуального ряду знецінює побутову реальність, темпоральна неоднорідність медіа дезорієнтує щодо фаз природних часових циклів тощо. Людина опиняється у ситуації тотального дефріциту відчуття дійсності, справжності і в міжособистісному спілкуванні, і в ситуаціях масової комунікації. Акцентування тілесного дозволяє виробити систему захисту від тотальної експансії технічних пристроїв або у всякому випадку створити ілюзію збереження безпосереднього, дійсного життя. Так, активно розвиваються і набувають статусів пріоритетних такі культурні практики, як дизайн, спорт, віртуальна комунікація тощо.

Рекреація людської природи, пошук безпосередніх контактів та органічності $€$ однією з провідних почуттєвих домінант сучасного світовідношення. Це визначає такі полярні напрямки формотворення, як рекреаційний, який зосереджується на відтворенні та збереженні традиційних, природних вимірів світовідчуття (екодизайн, DIY-культура, практики "здорового способу життя", "зеленого туризму", тренди "органічних продуктів" у харчуванні, косметології тощо), та нова органіка, орієнтиром якої $є$ заміна природного штучним (генномодифіковані продукти, штучні матеріали в одязі та будівництві, віртуалізація комунікації тощо).
Але найголовнішим виявляється переорієнтація самої людської активності на ідеали співтворчості, розвиток креатосфери. Взагалі серед мислителів сучасності поширена думка про необхідність широкого залучення креативності до механізмів прогресу, в чому вбачається вихід з глухого кута суспільства послуг. Розширення творчого потенціалу особистості може скласти підстави для спростування таких механізмів масової свідомості, як мода, ідеологія тощо. У прикладній творчості людина може вивільнитись від пресингу запрограмованості й тотальної типізації та уніфікації життя й повернути собі право визначати власний життєвий простір самостійно. В цьому сенсі можна говорити, що зазначена тенденція нарощування творчих індустрій змінить відчуженість, опосередкованість культурних практик повсякденності, здатна повернути у людське побутування онтологічне опікування буттям, але на новому рівні розвитку соціореальності та технологій.

Ностальгія за цілісністю спрямовує увагу формотворчих практик до архетипічного досвіду та етнотрадицій, на потенціал яких покладаються надії щодо повернення людині відчуття "домівки" через відновлення актуальності "гармонійного", "домірного". Цікавим в цьому сенсі виявляється те, що звернення до недосконалості, простоти, протиставленої "нудотно-благообразним" рекламним ідеалам, які відверто експлуатують споживацькі та сексуальні апетити, повертає життєвому простору право бути сповненим емоційно-евокативними кодами різного роду. Східна культура, з її традицією збереження права "потворного" на повноцінну участь в естетоссрері предметності та культом простоти й невимогливості, стає орієнтиром відповідних дизайнерських експериментів. Ця тенденція відображається у популярному сьогодні понятті "екологічного простору", яке базується на визнанні самоцінності всіх виявів життя й конституюється поняттям гармонійного на відміну від ідеального або доцільного.

У практиці професіоналів дизайну концепція "екологічного простору" включає не тільки традиційний набір вимог щодо температурно-кліматичного режиму, освітлення, безпечності матеріалів та комфортності, а й збереження особистісного, персоніфрікованого його компонента, тобто вільного від заангажованості дизайнконцепціями та технологічними устроями. Чистота стилю тут поступається природності відчуттів. 3 точки зору естетики важливо підкреслити, що людина на нових етапах культурного поступу знов і знов повертається до вихідних засад свого світосприйняття - почуттів, емоцій, відчуттів. Використання архетипічного досвіду, з його багатством символіки та метафоричності, покладене в основу екологічно спрямованого формотворення, створює засади його деінтелектуалізації, безпосередності. К. Рашид, представляючи свій проект "Ідеальний дім", активно використовує новітню матеріальність - техноорганіку - нову "біомасу", заряджену інтерактивними нововведеннями цифрової епохи: "До цього дому не треба звикати - він миттєво утворює симбіоз із своїм володарем, огортаючи відчуттям безпомилкової відповідності нашим бажанням" [9, с. 47]. Форми проекту апелюють до архетипів первісного житла, зонування проводиться за принципом інтеграції, а сам дім $€$ утіленням поняття "первісного техно". Ідеал "дім-як-сукня", який висуває К. Рашид, - новий виток реабілітації повноцінності, діалектичності та позитивності взаємин людської природи 3 оточенням, він може і повинен бути здійснений через легітимацію нової предметності: "Нові об'єкти, що формують наше життя, - стверджує дизайнер, - це трансконцептуальні, мультикультурні гібриди. Вони можуть існувати у будь-якому контексті - натуральному і синтетичному, породженому світом телекомунікацій, технологій, інфрормації і нового способу життя" [9, с. 47]. 
Популярний сьогодні напрямок дизайн-активності система "розумний дім" (Smart Home) - також демонструє тенденцію нового характеру взаємин людини та її оточення. Розумний дім - це не тільки автоматизація житлового або суспільного простору (автоматичне вмикання та вимкнення світла, програмування домашньої техніки, підтримка мікроклімату, інтеграція аудіо- та відеосистем, охоронна система тощо). У буквальному значенні це дім, який розуміє свого хазяїна, служить людині, а не примушує її пристосовуватись до умов середовища. Комфортність давно вже завоювала позиції визначального чинника формотворення, стала його провідною координатою. Але тепер вона набуває цього статусу навіть у суто естетичних та емоційних вимірах.

Ще один сучасний напрямок архітектурно-дизайнерських експериментів - дисипативна архітектура Філіпа Біслі, що надихається дослідженнями штучного інтелекту та досягненнями синтетичної біології й створює інсталяції 3 інтерактивним середовищем високої складності. Найвідоміша з них - Hylozoic Series - зайняла 1-ше місце на конкурсі Art and Artificial Life VIDA. Автор обирає вихідною точкою живу систему, таку як густозаселений ліс, й створює архітектуру, що здатна обробляти нестабільні умови, модулює середовище, отримує інформацію про його наповнення через кінетичні механізми з мікропроцесорами та датчиками. Це простір, що вибудовується, вивчаючи поведінку своїх жителів [3].

У вимірах теперішньої культурної епохи набуває нової перспективи питання форми. 3 одного боку, відкриті сьогодні можливості її не лише предметного втілення ставлять під сумнів пряму залежність дизайну від науково-технічного прогресу як від джерела винайдення новітніх матеріалів та виробничих технологій, з іншого - переорієнтовують зв'язок з ним у сферу віртуального, де питання необхідності форм заміняються питаннями творення зрозумілих знакових систем - інструкцій та алгоритмів дії. Тенденція до дематеріалізації предметного середовища робить формотворення прихованим, внутрішнім процесом, а віртуальна реальність комп'ютерних засобів знищує його фрізичні межі або, у всякому випадку, трансформує саму фрізичну реальність.

Діалектика форми та образу втрачає своє традиційне співвідношення, сміливі експерименти проективної культури із законами образотворення утворюють специфрічне поле, де можливі будь-які варіації форм та смислів, але об'єднані законами естетичного впливу 3 елементами епатажу чи парадоксу. Для постмодерного світогляду вартими уваги постають предметні утворення, що створені на грі абсурдного і реального, шокуючого і звичного, містичного і зрозумілого. Важко визначити межі цих формотворчих пошуків - тут посуд може бути пухнастим, а кухонна шафра висіти у повітрі. Головною ж своєю метою дизайнери одностайно визнають пробудження почуттів і активізацію спілкування. Такі категорії некласичної естетики, як епатаж та шок, вповні втілюють естетичну специфріку впливу провокації.

Постмодерна реакція на необхідну в умовах масового виробництва та урбаністичного способу співжиття уніфікованість предметності проголошує нову естетичну якість - "екстраординарність". Прагнення індивідуалізувати життєвий простір, запобігти його анонімності, сповнити його відчуттями та емоціями спрямовує дизайнерські пошуки на створення предметів класу "Х" - екстраординарних, експресивних, екстремальних, ексцентричних. Дизайн в цьому сенсі виявляє безмежність свого потенціалу експериментування зі світом речовості - відповіді на багатоваріантність людської природи. Строкатість образів сучасної предметності уподібнюється портретній галереї людських типів. Відсутність границь "доб- рого смаку" уможливлює найфантастичніші та найексцентричніші образи, але завжди маємо за орієнтир, що всі вони виникають як дзеркальне відображення мімічних рухів обличчя людської культури. Усе розмаїття дизайнерських підходів до створення предметних форм, образів, конструкцій являє собою здійснене у проектній формі дослідження законів людської почуттєвості.

Але констатована мислителями сучасності криза людської культури свідчить, що нарощування технічної досконалості й ергономічної пристосованості світу не в змозі замінити відчуття цілісності середовища, коли воно вибудовується самими ритмами життя й існує органічно. Замість вибудовування цілісності навколишнього світу, що забезпечило б людині відчуття домівки, дизайн перетворює людський простір на супермаркет, а самій людині нав'язує рольові ігри навіть у найінтимніших її проявах. Як наслідок виникає відчуття стомленості людини від нав'язливості фоомотворчих практик. Г. Лола вбачає витоки цього негативного відчуття в установці на "супердоречність кожної речі, коли все до дрібниць індивідуалізовано, скрупульозно вирахувано й пристосоване до визначеного місця у буквальному смислі цього слова" [8, с. 213]. На думку дослідниці, виникає ефект перевантаженості, нібито "занадто доброго дизайну". Людина опиняється у світі обгорток, упаковок, етикеток, які позначають, маркують весь універсум предметності - від косметичних засобів до урбаністичних ландшафтів. Усвідомлення негативного тиску цього своєрідного панестетизму вносить корективи в аксіологічну орієнтацію дизайн-діяльності, переорієнтовує ії з "прекрасного" та "ідеального" на "гармонійне" та "природне". Обґрунтовуючи прихильність до органічних форм, один з провідних західних дизайнерів К. Рашид стверджує, що "органіці властива та дружність, яка робить предмет близьким до людини, дозволяє відчути спорідненість з ним, як 3 організмом. Це народжує близький контакт з предметним світом, почуттєве, навіть еротичне спілкування" [9, с. 50].

Висновок. Спираючись на розвідки теоретиків сучасної культури та практичні втілення людської формотворчої активності, доведено, що майбутнє культурних практик знаходиться у площині розробок "нової мови" формотворення, яка буде заснована на максимальному використанні потенціалів стосунків "людина - природа - техніка" й оперуватиме новими пластичними та віртуальними параметрами. Запланована незавершеність, невизначеність формовиявів, що реалізується у трансформативності, амбівалентності, поліморфічності, інтерактивності проектних продуктів, пропонує нові алгоритми людського побутування в світі, вільному від диктату фрункціоналізму, соціальних стандартів і стереотипів та включеному у креативні індустрії.

\section{СПИСОК ВИКОРИСТАНИХ ДЖЕРЕЛ}

1. Баева Л. В. Экзистенциальные риски информационной епохи. [Електронний ресурс] / Л.В.Баева - Режим доступу: http://emag.iis.ru/arc/infosoc/ emag.nsf/BPAle63962ee99dc45ac44257c120042ef7c

2. Баева Л. В. Электронная культура: опыт философского анализа. [Електронний ресурс] / Л. В. Баева // Вопросы философии, № 5, 2013. - С. 75-83 - Режим доступу: $\mathrm{http}: / /$ vphil.ru/index.php?option=com content\&task=view\&id=753\&ltemid=52

3. Бисли Филип. Семинар с CITA Studio и Королевской Датской Академией Искусств Школы Архитектуры. [Електронний ресурс] / Филип Бисли - Режим доступу: http://www.philipbeesleyarchitect.com/

4. Брижченко Н. С. Інтерактивність як чинник формування дизайну сучасного громадського інтер'єру: дис. на здобуття уч. ступ. канд. мистецтвознавства: спец. 17.00.07. : "Дизайн" / Н. С. Брижченко. [Електронний ресурс] - Харків, 2015. - 328 c. - Режим доступу: http://www.ksada.org/doc/bryzhachenko-diss.pdf

5. Бродель Ф. Матеріальна цивілізація, економіка і капіталізм, XVXVIII ст.: У 5 т.: [Пер. з фрр.] / Ф. Бродель - К.: Основи, 1995. - Т.1. - 543 с.

6. Бычков В. В., Маньковская Н. Б. Искусство техногенной цивилизации в зеркале естетики / В. В. Бычков, Н. Б. Маньковская // Вопросы философии. - 2011, № 4. - С. 62-72.

7. Вольф Д. В. Эволюция DIY-практик в сер. XX-н. XXI вв. / Д. В. Вольф // Теория и практика общественного развития. - 2015, № 3. - С. 164-167.

8. Лола Г. Н. Дизайн. Опыт метафизической транскрипции / Г. Н. Лола. - М.: Изд-во МГУ. - 1998. - 264 с.

9. Рашид К. Не бойтесь будущого / К. Рашид // Салон. - 2003. № 3(70) - C. 47-52. 
10. Тоффрлер Э. Третья волна / Э. Тоффлер; [пер.с англ.]. - М.: ООО "Издательство АСТ", 2004. - 784 с.

11. Шатин Ю. В. Дизайн будущего или будущее дизайна? / Ю. В. Шатин // Техническая эстетика. - 1990. - № 8. - С. 7-12.

12. Яцюк О. Г. Мультимедийные технологии в проектной культуре дизайна: гуманитарный аспект: автореф. дис. на соискание уч. степ. док. искусствоведения: спец. 17.00.06. : "Техническая эстетика и дизайн" / О. Г. Яцюк. - Москва, 2009. - 45 с.

13. Bruns A. Blogs, Wikipedia, Second Life, and Beyond: From Production to Produsage. - Peter Lang Inc., International Academic Publishers, $2008-418 p$

14. Jenkins Henry. Convergence Culture: Where Old and New Media Collide. - New York: New York University Press, 2006 - 368 p.

\section{REFERENCES}

1. Baeva, L. V. Ekzystencialnye riski informacionnoj epohi. [Existential risks of the information age]. Retrieved from http://emag.iis.ru/arc/infosoc/emag.nsf/BPA e63962ee99dc45ac44257c120042ef7c

2. Baeva, L. V. (2013). Electronic Culture: Experience of Philosophical Analysis. Voprosy Filosofii, 5, 75-83. Retrieved from http://vphil.ru/ index.php?option=com content\&task=view\&id=753\&ltemid=52 (in Russian)

3. Beasley, Philip. Workshop with CITA Studio and the Royal Danish Academy of Arts of the School of Architecture. Retrieved from http://www.philipbeesleyarchitect.com/ (in Russian)

4. Bryzhchenko, N. S. (2015). Interaktyvnist' yak chynnik formuvannya dizajnu suchasnogo gromads'kogo inter'eru [Interactivity as a factor in shaping the design of contemporary public interior]: dis. na zdobuttia uch. step. kand. mistezhtvoznavstva. Kharkiv. Retrieved from http://www.ksada.org/doc/bryzhachenko-diss.pdf
5. Brodel, Fernan. (1995). Materialnaya civilizaciya, economika $i$ kapitalizm XV-XVIII st. [Afterthoughts on Material Civilization and Capitalism 15th-18th Century], Vol. 1 Kyiv, Osnovy.

6. Bychkov, V. V., Mankovska, N. B. (2011). Iskusstvo tehnogennoj civilizacii $v$ zerkale estetiki [The Art of technogenic civilization in the mirror of aesthetics]. Voprosy Filosofii, 4, 62-72.

7. Volf, D. V. (2015). Jevoljucija DIY-praktik v ser. HH - n. XXI vv. [The evolution of DIY-practices of the middle of the XX - early XXI centuries]. Theory and practice of social development, 3, 164-167.

8. Lola, G. N. (1998). Dizajn. Opyt metafizicheskoy transkripcii [Design. The experience of metaphysical transcription]. Moskow, Izdatelstvo MGU.

9. Rashid, K. (2003). Ne bojtes' budushhogo [Do not be afraid of the future]. Salon, March, 47-52.

10. Toffler, Alvin. (2004). The Third Wave. Moskow, AST (in Russian).

11. Shatin, Yu. V. (1990). Dizajn budushhego ili budushhee dizajna? [The design of the future or the future of design?]. Technical aesthetics, 8, 7-12.

12. Yacyuk, O. G. (2009). Multimedijnye tehnologii v proektnoj cul'ture dizayna. [Multimedia technologies in design culture of design: the humanitarian aspect]. Avtoref. dis. na soiskanie uch. step. dok. Iskusstvovedenya. Moskow.

13. Bruns, A. (2008). Blogs, Wikipedia, Second Life, and Beyond: From Production to Produsage. Peter Lang Inc., International Academic Publishers.

14. Jenkins, Henry (2006). Convergence Culture: Where Old and New Media Collide. New York, New York University Press.

Надійшла до редколегії 25.09.17

А. А. Семененко, канд. филос. наук, ст. преподаватель

Национальная академия изобразительного искусства и архитектуры

ул. Вознесенский спуск, 20, г. Киев, 04053, Украина

\section{АКТУАЛЬНЫЕ КУЛЬТУРНЫЕ ПРАКТИКИ В ПРОЕКТИВНЫХ ИНДУСТРИЯХ СОВРЕМЕННОСТИ}

В статье анализируется связь актуальных формотворческих тенденций с новейшими культурными практиками, развитие которых обусловлено экономическим, техническим и социальным контекстом культуры. С использованием оптики культурной антропологии и определенных современными мыслителями доминант цивилизационного движения изучены векторы проективной активности человечества. Показана эволюция языка и целей предметных практик, обозначены и охарактеризованы новые архитектурно-дизайнерские стили (рециклине-, поп-, эко-, рекреационный, моушн-, медиа-, мультимедиа-, мультисенсорный дизайн и т. д.). Разнообразие дизайнерских стилей сегодня обусловлено в большой степени стремлением объединить разделенные ходом общественного прогресса интенции формообразования соответствие требованиям и характеру современности и сохранение онтологических основ, которые обеспечивают человеку ощущение "дома" и собственной индивидуальности. Гармонизировать их удается дизайнерским практикам, которые реализуют в проективности коммуникативный, интерактивный потенциал, сохраняя пространства пребывания человека живыми и человечными.

Ключевые слова: современная культура, культурные практики, просьюмеризм, партисипация, мультимедийный и мультисенсорный дизайн, екультура, гибридное искусство.

A. A. Semenenko, PhD, s. lecturer

National Academy of Fine Arts and Architecture

20 Voznesens'kyj Uzviz street, Kyiv, 04053, Ukraine

\section{UP TO DATE CULTURAL PRACTICES IN MODERN PROJECTIVE INDUSTRIES}

The article analyzes the connection between some forming relevant tendencies and the newest cultural practices, the development of which is due to economical, technical and social context. Such features as mass character, consumerism, innovativeness, integrality, media character, network and information unity, fundamentally transform the image of civilization and people's lifestyle. Human projective activity vectors are explored with terminological tools of cultural anthropology and civilizational movement dominants defined by modern thinkers. Evolution of language and aims of substantial practices are showed and new architectural and design styles, like recycling-, pop-, eco-, recreational, motion-, media-design and so on, are marked and characterized. Modern phase of art's development, that integrates it with other cultural practices, such as science, trade, production, communication, medicine, show-business, tourism, etc., which change its forms and nature (media-art, video-art, transmission-art, technological art (electronic, robot- and genomic-art, internet-art). All these types of architectural, design and artistic activity exist and are fulfilled in kind of intensive fusion, organizing and fundamentally changing human's habitat.

The variety of design styles are strongly connected today with the commitment to unify form-creating intentions, that had been disconnected during the movement of social progress, which means conformity with modernity's character and requirements while maintaining ontological basis that gives a human sense of home and self-identity. Designer practices that implement communicative interactive potential in projectivity while keeping spaces alive and human are able to perform this harmony. Hence, exploration of features and vectors of the embodied in real and virtual substance projective activity gives a deeper understanding of the sense of civilizational transformations and their connection with human's substantive dimensions.

Key words: culture, cultural practices, prosumption, participation, multimedia and multisensory design, e-culture, hybrid art. 